\title{
5 Smartphone transnationalism in non-Western migration regimes
}

\author{
Transnational ethnography of Uzbek migrant \\ workers in Russia
}

Rustamjon Urinboyev

\section{Introduction}

Much research has explored the reproduction of transnational communities and relations, with a particular focus on locality, identity and culture. However, the existing research emanates from case studies of immigrant communities in Western-type democracies, whilst we know little about migrant transnationalism in non-Western migration regimes, such as those in the Russian Federation (or Russia) where migrant workers are subjected to numerous human rights abuses and have limited possibilities for transnational activism and collective mobilisation. Moreover, the role of new media, such as smartphones and social media, in migrant transnationalism remains under-researched. Given the historical, sociopolitical and cultural differences between Western and post-Soviet societies, we cannot assume that the methodological tools and theoretical perspectives developed in Western contexts are necessarily applicable to Russia, where the repressive sociopolitical environment, lack of democratic culture and arbitrary law enforcement leave little room for migrant legalisation and transnational activism.

The above considerations inform my position in this chapter, which aims to contribute to debates within the migrant transnationalism literature in two distinct ways. First, I present the results of extensive multisited ethnographic fieldwork undertaken in Moscow, Russia and the Ferghana region of Uzbekistan. My case study examines Uzbek migrants in Moscow and their families and communities in the Shabboda village in Ferghana. Unlike in Western countries, where migrants establish relatively functional transnational communities, there is little in the way of an 'Uzbek transnational community' in Russia given the restrictive legal environment and antimigrant sentiments. Whilst Uzbek migrants' transnational activism is hardly visible in public places, I argue that rapid improvements in communications technologies (e.g., smartphones and social media) have enabled Uzbek migrants to remain in touch with their home societies, as well as create permanent, smartphone-based translocal communities in Moscow, typically centred around migrants hailing from the same mahalla or village in Uzbekistan. Like all transnational communities engaged in the production of locality and identity, Uzbek migrants based in Moscow maintain daily interactions with their village. What makes this community distinct is that they reproduce and rely on their

DOI: $10.4324 / 9781003176763-5$ 
village-level identities, social norms and relations (e.g., reciprocity, trust, obligation, age hierarchies, gossip and social sanctions) as a form of law and governance when regulating their contractual obligations and relations in the informal migrant labour market.

The existence of this smartphone-based transnational environment helps migrants cope with the challenges of musofirchilik (being alien) and avoid or manoeuvre around structural constraints such as complicated residence registration and work permit rules, social exclusion, racism and the lack of social security. Based on a 'thick' ethnography, here I advance the notion of 'smartphone-based migrant transnational communities' as a subset of the migrant transnationalism literature that describes hidden and low-profile transnational practices, relations, identities and networks in nondemocratic political regimes. Such communities emerge as a necessity to cope with the repressive political environment, xenophobia, weak rule of law, lack of social security and risks associated with informal employment.

\section{Conceptualising smartphone transnationalism in nondemocratic migration locales}

Transnationalism has undoubtedly become a fashionable research topic within migration studies (e.g., Schiller et al. 1992; Portes et al. 1999; Vertovec 1999; Levitt 2001; Mazzucato et al. 2017). The initial view confined the study of migratory processes to the territory of a single nation-state (Park 1964; Lieberson 1980; Williams 1989). That view appears to have lost validity given the explosive growth of new communications and transportation technologies allowing individuals to maintain daily cross-border connections more affordably and more easily accessible than ever before (Ito and Okabe 2005; Hamel 2009; Hunter 2015; Ryan et al. 2015). Whilst acknowledging long-standing forms of migrants' connections to their homelands, current studies argue that today's linkages differ from these earlier forms given rapid developments in new media, such as smartphones and social media. Thus, migrants can be 'simultaneously situated' in multiple geographically and culturally distinct worlds, thereby blurring the distinction between 'here' and 'there' (Portes et al. 1999; Levitt and Schiller 2004; Licoppe 2004; Vertovec 2004; Nedelcu 2012).

Accordingly, transnational practices represent a part of everyday life for a growing proportion of migrants worldwide (Warf 2013). These global trends are especially visible in the scholarly literature on migration and technology, where information and communications technologies (ICTs) are viewed as central drivers of migrant transnationalism (Licoppe 2004; Vertovec 2004; Horst 2006). Initially limited to a number of case studies and review articles (Vertovec 2004; Wilding 2006) focused on cheap telephone calls and emails, research on migration and ICT is increasingly gaining ground. Scholars have not only explored the range of ICTs used and their role in increasing the frequency and intensity of transnational practices (Bacigalupe and Cámara 2012; Perkins and Neumayer 2013) but have also attempted to explain their empowering effects related to forging closer 
emotional bonds within transnational families (Benítez 2012). As such, studies have demonstrated that ICTs provide new possibilities for transnational caregiving (Baldassar 2008), long-distance relationships (Aguila 2009) and 'mobilephone parenting' (Madianou 2012). This leads to the construction of co-presence through constant and real-time exposure to one's home (Estévez 2009).

Another line of scholarly work focuses on diasporic websites, online fora and hometown websites, suggesting that ICTs enable migrants to maintain cultural practices across borders and to construct the feeling of a home away from home (Nedelcu 2012). This, in turn, creates new forms of transnational identities, networks and imagined communities (Hiller and Franz 2004; Mallapragada 2006; Castro and Gonzalez 2009).

However, critical views, often from anthropology and cultural studies, have also shown that the availability of ICTs can accentuate social pressures on migrants by left-behind family members as well as exert control by home countries' governments. Examples include the extensive surveillance of migrants by their home-country governments through the monitoring of their online postings, blogs and newsgroups (Bozzini 2015); family tensions and conflicts between migrants and their left-behind families (Baldassar 2008); increasing financial pressure on migrants (Hunter 2015); and jealousy within transnational couples (Hannaford 2015) triggering high levels of emotional strain on relationships (Wilding 2006).

Despite this extensive and diverse scholarship on the relationship between migrant transnationalism and technology, one pattern emerges as consistent across studies: they primarily focus on 'old' forms of ICTs such as emails, diasporic websites, online fora, cheap international calling cards and mobile phones. Within this literature, relatively few investigations exist documenting the impact of new media, such as smartphones and social media platforms, on migrant transnationalism (cf. Aricat 2015; Madianou 2016; Yoon 2016; Urinboyev 2017). This oversight persists despite new media's emergence as part and parcel of the everyday lives of migrants and their left-behind families and communities in many parts of the world. Undoubtedly, continuity exists between 'older' and new media, but the questions remain as to whether and how these new technologies shape the nature of transnational practices. That is, how do these processes manifest themselves in the everyday lives of migrants and their left-behind communities? And, what implications do they have for existing frameworks of migrant transnationalism?

Another factor adding to this lacuna is that much of the scholarly literature on transnational migration relies on case studies of immigrant communities living in Western democracies such as Australia, Canada, Spain, the United Kingdom and the United States (e.g., Barbero 2013; McLaughlin 2010; Charsley and Liversage 2013). Yet much less has been said about migrants' transnational practices in nonWestern locales, including, for example, Central Asian migrant workers in Russia. Russia is one of the five largest recipients of migrants worldwide, with the Central Asian republics representing some of the most remittance-dependent economies globally (UNPD 2017). Given the sociopolitical and cultural differences between 
Western democracies and post-Soviet countries, methodological tools and theoretical perspectives developed in Western contexts may not necessarily translate well to illiberal political regimes such as that in Russia. In this context, the repressive sociopolitical environment and lack of democratic culture leave little room for transnational activism and diasporic mobilisation. Armed with the 'varied geographies of transnationalism' perspective (Dunn 2010), it is reasonable to assume that migrant transnationalism is not the same everywhere, holding different meanings, forms and functional roles depending upon the sociopolitical context, legal environment, economic system and cultural factors. Addressing this research gap is particularly important when considering the growing use of smartphones and social media tools amongst Central Asian migrants in Russia. Such a study may provide new insights on transnational practices within undemocratic and repressive contexts. Thus, the question becomes: What are the implications of the Russian migration context, combined with a focus on smartphones and social media, for migrant transnationalism and technology scholarship, as well as for broader debates within migration studies?

This chapter contributes to debates on migrant transnationalism and technology and, more generally, to migration studies in three distinct ways. First, unlike Western democracies, where a strong culture of the rule of law exists, Russia is characterised by a weak rule of law, corruption, a poor human rights record, a weak civil society and widespread xenophobia (Ledeneva 2013; Abashin 2016). This implies that Central Asian migrants in Russia can hardly engage in collective action or transnational activism, given the structural constraints and widespread antimigrant sentiments. Nonetheless, Central Asian migrants do engage in transnational practices and reproduce their cultural repertoires and norms in their host country, but their transnational practices, networking and place-making primarily occur in a virtual environment. This results from the restrictive sociopolitical environment, corrupt legal system and widespread xenophobia compelling migrants to limit their visibility in public places (e.g., parks, streets, shopping malls and public transportation) and carry out their transnational practices and relationships via smartphones and social media. The role of ICTs in shaping everyday transnationalism is well researched within migration studies. Yet, within the Russian context, smartphones and social media are not merely tools for being 'here' and 'there'. More importantly, such tools are also crucial to migrants' daily survival and livelihoods in a repressive and xenophobic environment. In this sense, they provide a virtual platform for various risk-stretching activities and social safety nets unavailable from the migrants' home and host countries. I investigate these processes through multisited ethnographic fieldwork in Moscow, Russia and the Ferghana region of Uzbekistan.

Second, I use the aforementioned 'thick' ethnography to advance the notion of 'smartphone-based migrant transnational communities' to describe smartphone-based transnational practices in the context of undemocratic political regimes. Like all other transnational communities engaged in the production of culture, networks, locality and identity, Uzbek migrants in Moscow maintain 
daily interactions amongst themselves and with their left-behind communities in Uzbekistan. However, their transnational practices, relationships, identities and networks are primarily conducted via smartphones and social media applications. Furthermore, such practices emerged as a way to cope with Russia's repressive political environment, xenophobia, weak rule of law, lack of social security and risky shadow economy employment. Due to these risks and uncertainties, Uzbek migrants increasingly rely on smartphones to organise their precarious livelihoods. Thus, smartphones and social media serve as the everyday technologies of transnational place-making, enabling Uzbek migrants to reproduce their villagelevel identities, social norms and relationships across vast distances. These smartphone-based transnational interactions also serve as a 'legal order', regulating contractual relationships and obligations amongst migrants, exerting an identifiable impact on the outcomes of many practices Uzbek migrants (and other actors) engage in whilst in Moscow.

Third, within the post-Soviet migration literature, few scholarly investigations have focused on Central Asian migrants' transnational practices within the Russian context. Despite a growing interest on migratory flows and processes in the post-Soviet context, the literature on migrant transnationalism, particularly with regard to Central Asian migrants in Russia, remains limited to a few review articles and empirical studies (Atabaki and Mehendale 2004; Laruelle 2007; Ruget and Usmanalieva 2011; Schröder and Stephan-Emmrich 2016; Turaeva 2019). Existing research focuses on push-and-pull factors (Schmidt and Sagynbekova 2008) as well as the economic and political impact of labour migration (Laruelle 2013), discrimination, xenophobia and difficult working conditions (Round and Kuznetsova 2016), sexual risks (Weine et al. 2013) and migrant strategies for dealing with the repressive legal environment in the host country (Reeves 2013). In addition, a growing body of anthropological literature has examined the effects of migration and remittances on the ritual economy, gender-based power relationships, traditions, social norms, status and hierarchies within the sending communities (Reeves 2012; Kikuta 2016). One common thread across these studies lies in their focus on social processes and events occurring in either the migrant-sending or recipient society, but not both. Drawing upon multisited ethnographic fieldwork in Moscow and Ferghana, this chapter represents one of the first 'thick' descriptions of migrant transnationalism (with a combined focus on new media) in the Russian context.

I proceed in this chapter as follows. In the next section, I describe the methodology and ethnographic fieldwork I conducted in Moscow, Russia and Ferghana, Uzbekistan. I, then, provide an examination of the sociopolitical and legal context of the migrant labour market in Russia, allowing for an understanding of the nuances of the Russian context as well as the basic characteristics of the case study group, Uzbek migrants. Finally, I present the empirical material and analysis, and outline the implications of the ethnographic material for migrant transnationalism and technology debates, and, more broadly for migration studies. I conclude by highlighting the study's theoretical and empirical contributions. 


\section{Methodological considerations}

Rather than a specific ethnographic project on migration and technology, the research presented here stems from a project examining migration and legal cultures in post-Soviet societies. Thus, the research aims and questions explored can be described as an unexpected but intriguing discovery made during fieldwork. The ethnographic material presented relies on 13 months of fieldwork in Moscow and Ferghana conducted between January 2014 and May 2017. These field sites were chosen because Moscow has Russia's largest number of Uzbek migrants, whereas Ferghana is the primary migrant-sending region in Uzbekistan given its population density and high unemployment rate. I collected a rich stock of ethnographic material primarily through observations and informal interviews. Due to my Uzbek ethnicity, village origin and cultural competence, I was well connected to the Uzbek migrant worker community in Moscow and their left-behind families and communities in Ferghana. These factors enabled me to participate in the daily life of migrants, thereby becoming 'svoi' ('one of us, those who belong to our circle'), a term widely used in the post-Soviet context to refer to a person who has internalised the norms and values of a particular social group. In addition to traditional ethnography, I conducted a digital ethnography between January 2014 and June 2020 by following Uzbek migrants' daily discussion pages on social media platforms (Facebook, Odnoklassniki and Telegram Messenger), such as 'My migranty' (We are migrants), 'Migrant', 'Musofirlar taqdiri' (Migrants' fate) and Radio Free Europe's 'Sizdan Telegram' (Telegram from you).

All informants were asked for their consent to participate in this study. Given the sensitive nature of the data, I have changed the names and locations of all informants and omitted any information that could identify the individuals concerned. Because I collected ethnographic materials in two different locations, I present the data separately for each locale. This allows me to provide a detailed and clear description of my fieldwork, including data collection strategies and the selection of informants and fieldwork sites.

First, in Moscow, I conducted observations at construction sites, bazaars, cottages, farms, dormitories, shared apartments, Uzbek cafes, railway stations and on the streets where Uzbek migrants worked, lived and socialised. My observations frequently turned into informal chats and interviews due to the numerous questions that arose on the spur of the moment. Thus, I applied various strategies during my fieldwork. These strategies included, for example, renting mattress space in shared apartments where migrants lived, participating in migrants' daily construction work activities, accompanying migrants on the streets and public transport where they are often stopped and frisked by police officers, inviting migrants for lunch or dinner to cafes and 'hanging out' with migrants in bars. In addition, I maintained regular contact with informants via social media-based 'village groups', where they share various news items, videos and photos, update one another with Moscow and village news and spread gossip and rumours when someone acts unfairly towards other co-villagers. These experiences convinced me of the centrality of smartphones to Uzbek migrants' daily 
survival and livelihoods, which eventually became a key focus of my fieldwork. My observations and informal interviews generated first-hand information on migrants' smartphone-based transnational environments, the various collective and individual coping strategies they employed within that environment, the ways in which they managed and maintained transnational relationships with their leftbehind communities and the ways in which they reproduced and enacted their village-level practices, norms and identities in their daily lives in Moscow.

Second, and simultaneously, to keep up with the pace of developments in Uzbek migrants' lives in Moscow, I conducted observations and informal interviews in the Ferghana region, in a village I call Shabboda, from whence most informants/ migrants originated. I aimed to explore the processes of everyday material, emotional, social and symbolic exchanges between Shabboda and Moscow and how these transnational interactions shaped the lives of Uzbek migrants in Moscow. Given my svoi status, I had direct access to all social spaces within the village, enabling me to gather first-hand information about Uzbek migrants' and their left-behind families' and communities' daily transnational interactions. Again, the role of smartphones was crucial in transnational relationships. Many villagers I met possessed smartphones thanks to remittances sent from Moscow. During my fieldwork, I regularly visited migrants' left-behind families and carried out observations and informal interviews at the village's 'gossip hotspots' such as the guzar (community socialising space), choyxona (teahouse), gaps (regular get-togethers) and life-cycle events (e.g., weddings and funerals) where many villagers, including women, children and religious leaders, came together on a daily basis and conducted the bulk of the village's information exchanges. Because I typically met more than ten villagers on a daily basis during various social events, situations and spaces, it is difficult to pinpoint the exact number of individuals with whom I chatted during these site visits. Instead, the narrative I provide in the empirical section can be understood as a composite of the voices of the hundreds of villagers I encountered during daily visits to the guzar, choyxona, gaps, wedding feasts, circumcision ceremonies and funerals.

In addition to the ethnographic study, between July and August of 2015, I also conducted 100 semi-structured (in-depth) interviews with Central Asian (Kyrgyz, Tajik and Uzbek) migrant workers. I aimed to investigate the extent to which the findings from this ethnographic study (observations and informal interviews) are common amongst Central Asian migrants more broadly in Russia, so as to add more depth and detailed information to the ethnographic material and allow for some degree of generalisation. I, thus, conducted face-to-face interviews, through a conversational process, which lasted from 35 minutes to one hour. The interview questionnaire consisted of 91 open-ended questions and covered 15 different themes: (1) background and demographic questions; (2) the migrant labour market and working conditions; (3) immigration laws, actors and legal protection; (4) work permits and residence registration; (5) reentry ban and deportations; (6) street institutions, such as racketeers; (7) middlemen; (8) relations between migrant workers and the police; (9) corruption and bribes; (10) relations between migrant workers and immigration officials; (11) migrant 
workers' legal culture and their knowledge and experiences with immigration and labour laws; (12) migrant workers' informal coping strategies; (13) discrimination and racism; (14) migrants' social networks; and (15) migrants' transnational ties and practices. In selecting migrants for the in-depth interviews, I paid particular attention to diversity across ethnicity, country of origin, citizenship, age, gender, social status, occupation, educational background, Russian-language skills, legal status and migration experiences (experienced or newly arrived migrant).

Briefly, the basic characteristics of my informants were as follows: $92 \%$ were male, given the reality of the gendered constitution of Central Asian migrants (approximately $80 \%$ of all Central Asian migrants are male). In addition, the majority of the interviewees were young, ranging in age from 21 to 45 years $(92 \%)$, married $(62 \%)$ and had completed upper secondary school or vocational education $(84 \%)$. In terms of employment, they worked in construction $(55 \%)$, at a supermarket $(10 \%)$, as a cleaner and in housing maintenance $(8 \%)$, in a warehouse $(5 \%)$, as a domestic worker $(4 \%)$, as a taxi driver $(4 \%)$, in a bakery $(3 \%)$ and in other sectors $(11 \%)$. Only one-third of the informants $(31 \%)$ could easily communicate in the Russian language. In terms of sampling, I used random, snowball and purposive sampling techniques to increase the diversity of my informants. I conducted interviews at 15 different locations in Moscow city and the Moscow province, in diverse settings and situations such as Uzbek cafés and choyxonas, bazaars, shared apartments, construction sites, dachas (summer cottage), parking garages, auto service centres, dormitories, furniture workshops and random street interviews in localities known for high migrant clustering. In this chapter, I present only a small portion of the interview data, which specifically focuses on the transnational ties and practices of Central Asian migrants. A more comprehensive description of the interview data and accompanying results can be found in both previous and forthcoming publications (Urinboyev 2016; Urinboyev 2017; Urinboyev 2018; Urinboyev 2020).

\section{Uzbek migrant workers in Russia}

Labour migration from Uzbekistan to Russia began only in the mid-2000s (Abashin 2013). According to statistics from June 2019, nearly 2.2 million Uzbek citizens were present within the territory of the Russian Federation (RANEPA 2019). The majority of Uzbek migrants in Russia are male, young, low skilled with a vocational college education and originate from rural areas or small towns (Abashin 2014). Most Uzbek migrants originate from the densely populated Ferghana Valley, where unemployment remains high (Laruelle 2007), and primarily work in the construction sector, agriculture, retail trade, service industry or transportation (Chikadze and Brednikova 2012). Because of the high cost of accommodation and precarious working conditions, migrants rarely bring their family members with them to Russia (Abashin 2014). Thus, migrants typically send their earnings home to provide for their families' daily needs and other expenses (e.g., building a new house or buying a car, life-cycle rituals, medical treatment and education) that cannot be met locally given the economic realities in Uzbekistan (Ilkhamov 
2013). For the majority of Uzbek migrants, permanent settlement in Russia is not the primary goal. Instead, they remain in Russia for two to three years on average (Urinboyev and Polese 2016). Whilst Uzbek migrants spend most of their time in Russia and rarely visit home, they regard their situation as 'temporary', and maintain close ties with their family and mahalla (neighbourhood community), assuming that they will eventually return to their homeland (Abashin 2014).

Under a Commonwealth of Independent States (CIS) agreement between Russia and other post-Soviet countries, citizens of Uzbekistan are allowed to stay in Russia without a visa for up to 90 days. However, despite this visa-free regime, Uzbek migrants must obtain residence registration and a work permit in order to legally work in Russia. Precious few comply with these requirements given their low salaries, language test requirements and the prohibitively expensive work permit fees (Reeves 2015). This situation is further exacerbated by the notoriously corrupt Russian legal environment (Ledeneva 2013). Furthermore, even those migrants in possession of all of the necessary paperwork are not exempt from experiencing problems when they interact with law enforcement institutions (Round and Kuznetsova 2016). Under such circumstances, the status of 'legal' or 'illegal' hinges upon migrants' knowledge of 'street life' and their ability to adapt to the weak rule of law (Urinboyev 2016). As such, many Uzbek migrants work in the shadow economy, where they can survive without language skills and documents (Urinboyev 2018). This trend is supported by Russian authorities' statistics showing that nearly three million foreign nationals in Russia have violated their legal terms of stay (Pochuev 2015). Some experts estimate that the number of undocumented migrants in Russia could be much higher than official statistics, reaching around five million (Ryazantsev 2008; Chikadze and Brednikova 2012).

Since the majority of Uzbek migrants remain undocumented and work in the shadow economy, Russian employers have a strong incentive to exploit migrants and withhold or delay payment of their salaries. This results from the fact that claims related to transactions that take place within the shadow economyoutside labour regulations and tax codes - cannot be heard in state courts according to the Russian Civil Code. Moreover, migrants might be reluctant to approach state institutions, since doing so would reveal their undocumented status and invite punishment by the state. Even those migrants who possess all of the required permits and work legally cannot be certain that they will receive payment for their work. Human rights groups and civil society institutions have documented that Uzbek migrants (and migrants from other post-Soviet republics) experience numerous abuses, such as exploitation, discrimination, unsafe working conditions, wage theft and physical violence (Human Rights Watch 2009). In addition, Uzbek migrants must deal with corrupt police officers who view migrants as a source of kormushka ('feeding trough') (Urinboyev 2020). Even when documented, migrants are often asked for bribes when stopped by the police on the street or in the metro (Round and Kuznetsova 2016). Furthermore, Uzbek migrants experience racism on a daily basis. A 2016 survey conducted by the Levada Centre showed that the majority of Russians (52\%) agreed with 
the statement 'Russia for ethnic Russians' and nearly $70 \%$ of respondents felt that the government should restrict the influx of Central Asian migrants and undocumented migrants should be expelled from Russia (Pipia 2016). Thus, the everyday lives of Uzbek migrants feature a constant sense of insecurity threatened by exploitation, deportation, police corruption, racism, physical violence and even death.

Accordingly, given their semilegal status and involvement in the shadow economy, Uzbek migrants maintain a low profile and do not gather in public places. Today, anyone walking on the streets of Moscow can easily spot police officers checking the documents of Central Asian migrants. Therefore, Uzbek migrants try to make themselves as invisible as possible in order to avoid the attention of hungry police officers who often seek reasons to extort money from them (Urinboyev 2017). Consequently, Uzbek or other Central Asian migrants have few opportunities to publicly express and enact their transnational practices and diasporic identities in Russia (Urinboyev 2018).

Despite these challenges, rapid improvements in communications technologies (e.g., smartphones and social media) have enabled Uzbek migrants to create smartphone-mediated transnational identities, communities and activities in Moscow. These typically involve migrants from the same mahalla, village or town in Uzbekistan. Furthermore, these transnational practices are distinct in the sense that they are conducted exclusively in a virtual environment, without involving frequent physical, face-to-face interactions amongst migrants. That is, Uzbek migrants' transnational place-making practices occur via smartphones and social media. Such smartphone-based transnational communities are crucial to migrants' survival and provide alternative avenues to adapt in an otherwise repressive sociopolitical environment, by, amongst other things, devising specific survival strategies, creating intragroup solidarity, distributing information about jobs and building an informal social safety net to share livelihood risks and deal with emergency situations (e.g., medical treatment or repatriation of a deceased individual to their home country). Thus, an important feature of the Russian migrant labour market is the presence of a smartphone-based transnational world of migrants based on its own economy, legal order and welfare infrastructure.

In the next section, I present a 'thick' description of these processes. This description relies on ethnographic material from the everyday lives and experiences of Uzbek migrants in Moscow and their family members and communities in the Shabboda village in Ferghana.

\section{The Uzbek context: village-level social norms and cultural codes}

The village of Shabboda, located in the Ferghana region of Uzbekistan, is one of the most densely populated villages in the region, with approximately 18,000 inhabitants. Administratively, the Shabboda village is divided into 28 mahallas (neighbourhood communities). Each mahalla consists of 150 to 300 households (oila), consisting of around 20 to 30 kinship groups (urug). Many village residents work in the agricultural sector, primarily specialising in cucumber and grape 
production. However, for the past ten years, remittances sent from Russia have become the primary source of survival (tirikchilik) for many households.

At the time of my fieldwork, most village residents had sons or close relatives working in Russia. The proportion of women migrating to Russia was also increasing in the village. Daily conversations in Shabboda revolved around the adventures of village migrants in Moscow, the amount of remittances, deportations and entry bans. Most villagers owned smartphones with internet access, enabling them to exchange daily news with co-villagers residing in Moscow. In this way, absent migrants were 'present' in the village through smartphone-mediated daily information exchanges between Shabboda and Moscow. During my fieldwork, someone was always leaving for Moscow, where someone else was always waiting to receive that person, and someone was always returning to the village to attend a wedding or funeral ceremony. Shabboda, in the words of villagers, was a 'Moscow village', with most male villagers working in Moscow given the village networks existing there. Several villagers worked as middlemen in Moscow's construction sector serving as gatekeepers to villagers seeking access to the Russian migrant labour market. Thus, Shabboda was a truly transnational village, since everyday material, family and social exchanges directly connected it to and with Moscow.

Viewed from the macro-level perspective, these migratory processes represent the manifestation of broader social changes taking place in Uzbek society. Given the Uzbek state's failure to provide employment opportunities, today, in both urban and rural Uzbekistan, migration has become a widely accepted livelihood strategy used by millions of households to secure their basic needs (Ilkhamov 2013). As Salim (65, male), one village member, put it:

The state no longer exists in Uzbekistan and died shortly after the fall of the Soviet Union. So, we (Uzbek people) must choose between sending our children to clean the streets of Moscow or staying at home and waiting for the promised great future that will never come.

Given the 'absent state', villagers frequently rely on social safety nets and mutual aid practices that take place within the realm of their family, kinship group and mahalla. Villagers meet one another on a daily basis at the guzar and choyxona to discuss and arrange mutual aid practices, which, in turn, produce reciprocity, affection, shared responsibilities and obligations amongst villagers. These reciprocal relationships produce economic and social interdependency amongst villagers, generating an expectation that villagers should help and support one another, especially when they are in a vulnerable situation. Thus, social pressure and sanctions can be applied to a village member or her/his family and kinship group if s/he (or they) is (are) not acting fairly or not helping neighbours or village members who face a critical situation. Not wanting to encounter social pressures, villagers often try to help members of their family, kinship group or mahalla. These village-level norms, identities and mutual aid practices continue to shape the villagers' livelihoods even when they are in Russia. More interestingly, these processes are mediated by smartphones and social media. 


\section{The Russian context: reproducing Uzbek village practices and norms via smartphones}

Similar to Mexicans in the United States (Castro and Gonzalez 2009) and Indians in Singapore (Velayutham and Wise 2005), Uzbek/Shabboda migrants capitalise on their village-based identities and norms in their daily lives in Moscow. This is clearly illustrated by Halil (45, male), a village member who recently returned to his village for a short period to visit his family:

Even if we move to Russia, a foreign country, and stay there for five to six years, we (Shabboda migrants) continue to follow our old habits, religion and way of life. If one of us gets into trouble, we quickly inform our village members both there (in Russia) and here (in Uzbekistan) via Telegram (a smartphone app) or an ordinary phone call. We, the migrants in Moscow, quickly collect money and try to help our fellow villagers. If you turn away and do not help your co-villagers, information about your egoistic behaviour will quickly spread amongst migrants and also travel to the village via the internet (e.g., Telegram Messenger).

Accordingly, the existence of such village-based identities creates a sense of social responsibility amongst villagers that they must care for one another during their time in Russia. When talking to Shabboda migrants, it became apparent that their decision to migrate to Moscow not only stems from economic considerations but is also connected to kinship relationships between migrants, return migrants and non-migrants. Villagers believe that going to Moscow means joining the mahalla and village acquaintances there. Once they arrive at Moscow's Domodedovo or Vnukovo airport, they are quickly picked up by fellow villagers. Thus, villagers imagine their future migrant life as integrated into their village and mahalla networks which already extend to Moscow. Even those few Shabboda migrants who received Russian citizenship continue to actively engage in transnational practices since they believe that they will eventually return to Shabboda. This is particularly visible in the words of Ozoda (40, female) and her husband Akbar (42, male) who, despite holding Russian citizenship, are building a rather posh house in Shabboda. They obtained Russian citizenship not to permanently settle in Russia, but to navigate around the structural barriers and repressive legal environment.

Whilst most Shabboda migrants did not share communal accommodation or worked in different places in Moscow, they maintained daily contact with villagers in Moscow. They did so through smartphones, which they used to stay in touch with one another in Moscow, as well as to check the latest news, view photographs of Russian and Uzbek girls and make video calls to their families and village networks in Shabboda. Only a small group of migrants I encountered used social media to discuss Uzbek politics since most were afraid that doing so would invite unnecessary surveillance and punishment by their home country's government. Some migrants even speculated that they accidentally met several members of the Uzbek security services in Moscow who were trying to collect 
information about politically active or religious migrants. Due to these fears and suspicions, many Shabboda migrants were reluctant to talk about politics or religion in public settings. Instead, migrants primarily used smartphones to organise their precarious livelihoods and reproduce their village-level practices in a virtual environment.

The state is 'absent' not only in Shabboda, where villagers use mahalla-driven solidarity to create alternative public goods and services but also in Moscow, where solidarity with and support from mahalla networks compensated for the complete lack of security from Russian state institutions. Shabboda migrants were completely unaware of the existence of Uzbek diasporan organisations or migrant rights organisations that could provide some form of support. Additionally, they received little to no support from the Embassy of Uzbekistan in Moscow when experiencing problems with dishonest employers or corrupt police officers.

Given this complete lack of security, Shabboda migrants reproduced most of their village-level mutual aid activities in Moscow to compensate for the absence of formal protection mechanisms. Smartphones and social media applications served as platforms for carrying out such activities. Shabboda migrants, for example, quickly informed each other and mobilised resources when someone fell ill, was caught by the police, needed to send something home or desperately needed money. These smartphone-based transnational interactions were crucial to the migrants' survival and served as an alternative social safety net, as explained by Abduvali (38, male), a construction worker from the Shabboda village:

We usually avoid public places because there are hundreds of police officers on the streets, seeking to extort money from us (migrants). Instead, we use smartphones and social media to resolve problems, socialise with our co-villagers in Moscow as well as to maintain daily contact with our families, mahalla and village friends in Shabboda. It is Moscow, and things are unpredictable here; we rely on our village connections when we get into trouble. We are all migrants here, so we cannot turn our backs when our fellow villagers are in trouble. But, in order to reach your co-villagers, you must always have a mobile phone with you, and you must memorise their phone numbers. For example, let's assume that you are a migrant worker who is caught by a police officer and brought to the police station. Normally, police officers keep you in the cell for a few hours and check your documents very carefully, a thing usually do to further scare migrants. After finishing the check, police officers give you two options: (1) you can pay a bribe immediately and go home or (2) if you have no money, police officers allow you to phone your friends so that they can bring money and secure your release. The second scenario is more common, and you need to call your co-villagers for help. Therefore, you must always have your mobile phone with you. A police officer might allow you to use their mobile phone to contact your co-villagers, but not all police officers are nice. If you do not have a phone with you and are caught by the police, there is a high risk that the police officers will transfer your case to court for deportation. 
The repatriation of the deceased from Russia to Uzbekistan provides another relevant example of smartphone transnationalism. Shabboda migrants, like other Central Asian migrants (Reeves 2015; Round and Kuznetsova 2016), experience difficult living and working conditions in Moscow, including discrimination, hazardous working conditions and physical violence. They are, therefore, aware that the threat of death is ever present in their daily lives in Moscow. As one Shabboda migrant said, 'Death can be the fate of any migrant in Russia since we are working in a bespredel [limitlessness, lawless] country where anything can happen.' Aware of their own precarious livelihoods, migrants voluntarily contribute to repatriation expenses if someone from their mahalla or village dies from a work-related accident, disease or a neo-Nazi skinhead attack. Given these risks, Shabboda migrants tended to capitalise on their mahalla traditions (such as norms of reciprocity and solidarity, as well as good neighbourliness) as a means to cope with the challenges of being an alien in Russia. When someone was killed, news spread swiftly amongst villagers as migrants immediately contacted their mahalla networks via smartphones and social media. There was no standard amount for contributions, and migrants determined how much to contribute based on their financial situation and income level. Because the threat of death was ever present in migrants' lives, news of a death deeply affected everyone, and many migrants stepped forward to assist with the repatriation expenses. As such, Shabboda migrants viewed their contribution to body repatriation as a form of insurance in the case of their own death, as illustrated in the following:

I always make a contribution to body repatriation, because I know my co-villagers would do the same favour for me if I were to suddenly die from a work-related accident or disease. Body repatriation is a hashar-a collective mahalla project where everyone is expected to contribute. If you are greedy and do not contribute, there is a high likelihood that your body will not be taken care of if you die. Nobody wants his body to remain in Russia. We all want to be buried in our homeland. (Nodir, 26, male, migrant worker from Shabboda village)

Accordingly, smartphones and social media serve as the everyday technologies of transnationalism, reproducing and maintaining village-level identities, social norms and relationships across distances. Other studies have similarly shown that mobile phones do not 'fracture' localities, but extend and reproduce them in migrant-receiving societies (Pertierra et al. 2002; Vertovec 2004; McKay 2006; Nakamura 2013). However, the literature on ICTs and transnationalism tends to focus on their functional role, primarily exploring how ICT availability increases the frequency and magnitude of transnational interactions and blurs the distinction between 'here' and 'there'. The case of the Shabboda village demonstrates that smartphones and social media not only facilitate the intensity of everyday exchanges between Moscow and Shabboda, but, also, and more importantly, reproduce a virtual transnational community. This virtual community, then, 
regulates the daily practices and behaviour of village residents both locally and transnationally.

One episode I witnessed in Moscow illustrates how Shabboda-level norms and practices extend to Moscow through smartphones. One Wednesday afternoon - on 30 July 2014 - 'Zaur' and I were in the car heading towards a construction site in Balashikha, a small city in Moscow province where the majority of Shabboda migrants work. Unlike his co-villagers who work in the construction sector, Zaur works as a clerk at a grocery store in Moscow. This position granted him the nickname Russkiy (Russian) amongst his co-villagers given that he received a higher salary and was not obligated to engage in chornaia rabota ('black work' such as construction, agriculture or janitorial services). Because Zaur was considered more successful and better connected than other migrants, individuals from the Shabboda village often contacted him with requests.

As we neared the construction site, Zaur received a call on Viber (a smartphonebased free phone application) from Uzbekistan. He usually picks up calls from Uzbekistan and immediately answers them. It was Zaur's neighbour, 'Ozoda', who had an urgent request. From their phone conversation, I learned that Ozoda's husband, 'Ulugbek', who worked on a greenhouse farm in Vologda city, recently underwent an appendectomy and was on a train to Moscow. Ozoda was quite worried about her husband since he was physically unable to work and had no money to purchase a train ticket back to Uzbekistan. It was clear that Ozoda asked Zaur to help her husband return to Uzbekistan. After finishing the conversation, Zaur said that we needed to return to Moscow and meet Ulugbek at the Kazanskaya railway station when he arrived from Vologda. On our way to the station, Zaur told me that he was obliged to help Ulugbek and buy him a train ticket to Uzbekistan using his own resources. Zaur also made it clear that he would not be reimbursed because his assistance would be treated as a 'mahalladoshlik' (shared mahalla origin) obligation. This would not be the case if Zaur and Ulugbek did not live in the same mahalla.

Rather than travelling all the way to Moscow and then to Tashkent, Ulugbek could have taken a train directly to Tashkent if he had waited in Vologda for a further ten days. However, Ulugbek knew that he would be taken care of by his mahalla network if he travelled first to Moscow, where many Shabboda migrants are based, a reality that guided his decision. Ulugbek was also aware that Zaur would have difficulty refusing to help if his family members from Shabboda were involved in the process. Zaur told me that if he refused to help Ulugbek and other mahalla acquaintances, mahalla members would spread gossip about him. Of course, Zaur was in Moscow and could just ignore the gossip. But, he had to consider his family members' situation, since they would bear the consequences of his decision. Zaur hoped that at least Ulugbek would appreciate his help and tell fellow mahalla members about his odamgarchilik (good deeds). Therefore, to preserve his family's good reputation and prevent possible mahalla pressure and gossip, Zaur decided to help Ulugbek, even though doing so would cost him money and time. 
In addition to the train ticket, Zaur also had to cover other costs and concerns. For instance, he had to drive from Balashikha to the Kazanskaya railway station. By taxi, this trip typically costs at least 3000 roubles (approximately US\$50). Moreover, it is quite difficult to secure a train ticket for the next day since tickets typically sell out, requiring one to buy them at least three days in advance. Thus, Zaur had to bribe the train provodnik (conductor) and arrange a place (without a valid ticket) for Ulugbek. Many thieves and racketeers extort money from migrants at the Kazanskaya railway station. Given his many years of work in Moscow, Zaur took advantage of his multiple established connections at the railway station, ensuring that Ulugbek safely boarded the train and reached home without any problems.

Events unfolded exactly as Zaur described. We arrived at the Kazanskaya station at 4 PM. Ulugbek's train arrived one hour later. After meeting Ulugbek at the station, we all headed towards a small fast-food cafe, where migrants could secure fake work permits and residence registrations. There, we met an Uzbek woman who was well connected with the train provodniks. Zaur paid her 7500 roubles, and she then guided us through the station and quickly arranged a special seat for Ulugbek on a Moscow-Tashkent train. After a short conversation with the provodnik, she assured us that Ulugbek was now in safe hands and would be in Uzbekistan in five days' time. Zaur gave an additional 1000 roubles to Ulugbek and told him to use it for food expenses during the long trip. We shook hands with Ulugbek and watched as the train departed for Uzbekistan.

At the time of writing, the role of these smartphone-based transnational practices proved especially pivotal during the COVID-19 pandemic, which had dramatic and unprecedented effects on migrants' everyday lives in Russia and beyond. As the number of coronavirus cases drastically increased, Russia, in parallel with many other countries around the world, introduced strict lockdown measures to prevent the spread of the virus. Whilst Russian regions had some degree of autonomy in defining the level of COVID-related restrictions, in Moscow, where the majority of Shabboda migrants work, the city government introduced strict lockdown measures. As a result, a considerable number of Shabboda migrants, especially those working in the service industry, factories and bazaars, lost their jobs. This led to a 'catch-22' situation, whereby migrants neither had the savings necessary to cover their living expenses nor the possibility of returning to their home country due to travel restrictions introduced by the Russian government on 18 March 2020. Despite the COVID-related restrictions, some sectors of the Russian economy, notably, the construction sector, continued to operate. Since the majority of Shabboda migrants worked in the construction sector, they quickly assisted their unemployed co-villagers, providing them with temporary jobs and accommodation at construction sites. In cases when it was not possible to find jobs, villagers collected money, pooled their resources and provided food products to their members who needed it. These mutual aid practices were possible owing to the extension of village-level social norms, expectations and obligations that create a strong intragroup solidarity amongst migrants. 
In reality, such smartphone-based transnational practices can also be observed within various migrant communities in Russia. During my fieldwork, I also conducted in-depth (semi-structured) interviews with 100 Central Asian migrants (Kyrgyz, Tajik and Uzbek migrants) in Moscow between July and August 2015. Here, I provide some empirical findings from these interview data, focusing on their transnational ties, identities and practices and the role of smartphones and social media in these processes.

As Table 5.1 shows, more than half of migrants rely on their relatives and covillagers (zemlyaki) when they need urgent help. This illustrates the importance of a shared territorial origin and kinship relations in migrants' everyday lives in Russia. Thus, I argue that the mutual aid and social safety nets described in the Shabboda migrants' example also extend to other migrant communities.

Table 5.2 shows that it has become a norm amongst Central Asian migrants to collect money for body repatriation expenses. This practice even transcends village-level practices, whereby many migrants are willing to contribute to the repatriation costs even if the deceased migrant is not from their village or district in their home country.

The use of smartphones is also quite common amongst migrants, as shown in Table 5.3, testifying to the shift from the mobile phone to the smartphone era amongst migrant communities. Smartphone use, in turn, leads to a higher level of internet use and social media activism amongst migrants.

Table 5.1 Source of help when migrants are in need of urgent help

Q. Imagine yourself in a situation facing problems (e.g., if you are very ill or injured, short of money or cannot find accommodation) and you need urgent help. In such a case, who would you rely on?

My relatives and co-villagers (zemlyaki) also work in Russia, so I would rely on $58 \%$ them.

I would rely on my new friends that I have met in Russia. $\quad 14 \%$

I would rely on my employer. $\quad 13 \%$

I would rely on colleagues in my workplace. $\quad 12 \%$

I would try to solve my problems independently. All migrants have problems, $\quad 2 \%$ so I don't want to be a burden to others.

I would pray to and rely on Allah (God) during hardships. $1 \%$

Table 5.2 Body repatriation and the collective pooling of resources

Q. Imagine a situation in which one of the migrant workers dies and migrants are collecting money in order to transport the deceased by airplane to Central Asia (Kyrgyzstan, Tajikistan or Uzbekistan). How would you react if you are requested/ invited to make financial contribution to the transportation expenses?

Yes, I would contribute financially even if the deceased migrant is not my $\quad 89 \%$ acquaintance.

I would contribute if the deceased migrant is my friend or acquaintance. $\quad 11 \%$ No, I would not contribute. 
Table 5.3 The use of mobile phones amongst migrants

Q. Do you have a mobile phone? If yes, what type of mobile phone do you use?

Smartphone (Android/iPhone/Windows phone)

$69 \%$

Basic mobile phone (without any smartphone functions)

$31 \%$

I don't use a mobile phone

$0 \%$

Table 5.4 The frequency of internet use amongst migrants

Q. On average, how frequently do you access the internet?

Daily $\quad 73 \%$

Weekly $\quad 10 \%$

I don't use the internet $\quad 17 \%$

Table 5.5 Social media use amongst migrants

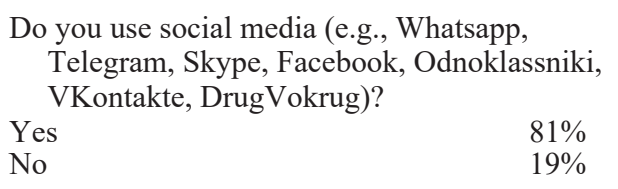

Due to the widespread use of smartphones, $73 \%$ of the migrants I interviewed stated that they use the internet on a daily basis (Table 5.4).

Accordingly, as shown in Table 5.5, $81 \%$ of interviewees regularly use social media applications, which I infer to mean that smartphone-based transnational practices are common not only amongst Shabboda migrants but also amongst the various migrant groups I interviewed.

Overall, a brief snapshot from the semi-structured interviews indicates that smartphone-based transnational practices and identities seem to be common amongst various migrant communities in Russia. Although the empirical material presented in this chapter focuses largely on Uzbek migrants' smartphone-based transnational practices, it is important to emphasise that these experiences are common to all Central Asian migrants in Russia and resonate with the experiences of other migrants from Armenia, Azerbaijan, Moldova, Syria and Ukraine given their exposure to similar sociolegal environments and structural constraints.

\section{Discussion and concluding remarks on smartphone transnationalism}

I have argued that much of the migrant transnationalism literature emanates from case studies of immigrant communities in Western democracies. As such, few studies have investigated these issues within non-Western migration contexts such as Russia, where a repressive and xenophobic environment leaves little room 
for (overt) transnational activism and the public expression of cultural identities. Referring to the sociopolitical and cultural differences between Western and postSoviet societies, I argue that migrant transnationalism may carry different meanings, forms and functional roles in the Russian context. Furthermore, I contend that the bulk of the 'migration and technology' literature focuses on 'older' forms of ICT, such as email, mobile phones and diasporic websites. Thus, here, I update this scholarship by examining recent technological developments, including smartphones and social media, which provide almost unlimited opportunities for transnational interactions. I have described these processes by ethnographically attending to the everyday transnational lives of Uzbek migrants in Russia and their left-behind communities in Uzbekistan. As the results indicate, unlike Western democracies, where migrants established relatively functional (also 'physically' visible) transnational communities and diasporic groups, very little in the way of an 'Uzbek transnational community' has been established in Russia given its repressive environment and antimigrant sentiments. Whilst Uzbek migrants' transnational activism remains primarily invisible in public places, I demonstrated that smartphones and social media platforms enable Uzbek migrants to remain in touch with their societies of origin. Such technology has also allowed migrants to create smartphone-based transnational community in Moscow, typically centred around migrants who hail from the same mahalla or village in Uzbekistan. The existence of a smartphone-based transnational environment helps migrants cope with the hardships of being alien, allowing them to avoid or manoeuvre around structural constraints. Thus, by exploring the interplay between migrant transnationalism and smartphones in a non-Western migration context, this chapter moves the migrant transnationalism literature beyond a Western-centric paradigm, providing new insights into the role of new media in migratory processes.

Through my ethnographic study of the Shabboda village and its smartphonebased transnational form in Moscow, I explored the ways in which the home village is maintained in Moscow as a social association through smartphones and social media. As I have shown, rapid improvements in ICTs enabled Shabboda migrants to remain in touch with their home village and to create a smartphonebased translocal community in Moscow. Whilst most Shabboda migrants in Moscow do not share communal accommodation and meet infrequently due to the punitive sociolegal environment, they are actively engaged in transnational place-making owing to smartphones and social media. It is this virtual space that I call the 'smartphone-based transnational community'. Whilst the Shabboda migrants' smartphone-based transnational community does not take on a material or physical form, their daily practices are clearly linked to a physical place and the maintenance of village-level social norms and relations. That is, their daily actions and decisions are determined by the norms of their home village. Thus, the migrants' smartphone-based transnational community orients towards the physical village - in this case, to Shabboda.

Empirically, this chapter adds to the post-Soviet migration literature (e.g., Atabaki and Mehendale 2004; Laruelle 2007; Ruget and Usmanalieva 2011; Round and Kuznetsova 2016; Reeves 2013, 2015). Most studies on post-Soviet 
migration, particularly those concerned with the Russian migration context, primarily focus on social processes occurring in either the sending or recipient society. By ethnographically exploring everyday transnational interactions between Moscow and the Shabboda village, this chapter moves beyond methodological nationalism (Wimmer and Glick Schiller 2002). Furthermore, it provides unique empirical material and insights on migrant transnationalism in post-Soviet societies (that may not be collected by other researchers). This results from my position - that is, my ethnicity, village background and language skills as well as through my extensive contacts - and my access to such practices.

Furthermore, this chapter offers important implications for the overall study of international migration. Through an ethnographic study of migrant transnationalism in Russia, I provide new empirical material on and comparative insights into migration studies in general. As previously mentioned, much of the migration literature relies on case studies of immigrant communities in Western democracies. This focus can be partly explained by the ongoing legacies of the 'three worlds division' of social scientific labour (Pletsch 1981; Chari and Verdery 2009), which continues to overlook the role and contribution of non-Western migrant-receiving contexts in the comparative and theoretical debates about contemporary migration systems. Simultaneously, non-Western societies have traditionally been viewed as 'exporting' migrants to Western Europe, North America and Australia (Castles and Miller 2009). Their role as magnets for labour migrants from other countries has, thus, been obscured. Addressing this research gap is particularly important when considering the fact that non-Western countries, such as Russia as well as Kazakhstan, Malaysia, Qatar, Saudi Arabia and Turkey, have become 'migration hotspots' worldwide resulting from their improved economic conditions (e.g., Gülçür and İlkkaracan 2002; Garcés-Mascareñas 2010; Anderson and Hancilová 2011; Gardner et al. 2013). Given these global trends, here I argue for the need to move beyond Western-centric paradigms and developing alternative frameworks for understanding migratory processes and social change in non-Western migration contexts.

As an aside, I should emphasise that this study carries some limitations in terms of gender dynamics and its overall generalisability. First, my fieldwork primarily focuses on male migrants. Ideally, I would have included the experiences of female migrants. However, this was a conscious choice dictated by the reality of the gendered constitution of Shabboda migrants in Moscow-90\% of such migrants were male. Another factor that led me to focus on male migrants had to do with my own gender (male). According to the cultural and religious norms in the Shabboda village, it is inappropriate for men to approach women when their spouses are not present. Not wanting to cause any inconvenience to female migrants, I decided to focus primarily on male migrants. Thus, this chapter highlights the need for further research covering the transnational experiences of female migrants in Russia. Another limitation to my research relates to the generalisability of my findings. Since I conducted an ethnographic study amongst Shabboda migrants in Moscow and their left-behind families in Ferghana, it remains to be seen how much and 
whether my findings can be extrapolated to other migrant communities in Russia. However, because both Central Asian and Caucasian migrants experience a similar sociopolitical environment in Russia and given that the use of smartphones is common amongst various migrant groups, we can assume that the findings here may prove relevant to understanding the general environment within the Russian context. That said, clearly, further research is needed in order to develop a deeper understanding of migrant transnationalism in Russia.

\section{Note on Transliteration}

Throughout this chapter, Russian and Uzbek terms are spelled according to the standard literary form based on the following two criteria: (1) whether a Russian/ Uzbek word or phenomenon is central to the study and (2) if an English translation does not fully capture the meaning of the Russian/Uzbek word or phenomenon. Russian and Uzbek words are presented in italics.

\section{Funding acknowledgement}

This research was financially supported by the following funding agencies: the Swedish Research Council (dnr D0734401), the European Commission H2020-MSCA- IF-EF-ST (grant number 751911), the Kone Foundation (grant identification code f577aa), the University of Helsinki (Three-Year Grants Programme) and the European Commission H2020-MSCA-RISE-2019 'Central Asian Law' (grant number 870647).

\section{References}

Abashin, S., 2013. Central Asian Migration. Russian Politics \& Law, 51 (3), 6-20.

Abashin, S., 2014. Migration from Central Asia to Russia in the New Model of World Order. Russian Politics \& Law, 52 (6), 8-23.

Abashin, S., 2016. Migration Policies in Russia: Laws and Debates. In: A.-L. Heusala and K. Aitamurto, eds. Migrant Workers in Russia: Global Challenges of the Shadow Economy in Societal Transformation. London: Routledge, 16-34.

Aguila, A.P.N., 2009. Living Long-Distance Relationships through Computer-Mediated Communication. Social Science Diliman, 5, 83-106.

Anderson, B. and Hancilová, B., 2011. Migrant Labour in Kazakhstan: A Cause for Concern? Journal of Ethnic and Migration Studies, 37 (3), 467-483.

Aricat, R.G., 2015. Mobile/Social Media Use for Political Purposes Among Migrant Laborers in Singapore. Journal of Information Technology \& Politics, 12 (1), 18-36.

Atabaki, T. and Mehendale, S., 2004. Central Asia and the Caucasus: Transnationalism and Diaspora. London: Routledge.

Bacigalupe, G. and Cámara, M., 2012. Transnational Families and Social Technologies: Reassessing Immigration Psychology. Journal of Ethnic and Migration Studies, 38 (9), 1425-1438.

Baldassar, L., 2008. Missing Kin and Longing to Be Together: Emotions and the Construction of Co-presence in Transnational Relationships. Journal of Intercultural Studies, 29 (3), 247-266. 
Barbero, I., 2013. Migrant Struggles and Legal Pluralism: Claiming Citizenship Across Multiple Scales. The Journal of Legal Pluralism and Unofficial Law, 45 (3): 357-71.

Benítez, J.L., 2012. Salvadoran Transnational Families: ICT and Communication Practices in the Network Society. Journal of Ethnic and Migration Studies, 38 (9), 1439-1449.

Bozzini, D., 2015. The Fines and the Spies. Social Analysis, 59 (4), 32-49.

Castles, S. and Miller, M.J., 2009. The Age of Migration: International Population Movements in the Modern World. Basingstoke: Palgrave Macmillan.

Castro, L.A. and Gonzalez, V.M., 2009. Hometown Websites: Continuous Maintenance of Cross-border Connections. In: John M. Carroll (ed.), Proceedings of the Fourth International Conference on Communities and Technologies. New York: ACM, $145-154$.

Chari, S. and Verdery, K., 2009. Thinking Between the Posts: Postcolonialism, Postsocialism, and Ethnography After the Cold War. Comparative Studies in Society and History, 51 (1), 6-34.

Charsley, K. and Anika, L., 2013. Transforming Polygamy: Migration, Transnationalism and Multiple Marriages Among Muslim Minorities. Global Networks, 13 (1): 60-78.

Chikadze, E. and Brednikova, O., 2012. Migrants from Uzbekistan in Russia: Communicative Strategies and Practices of Consuming (mass-media) Information. Saint Petersburg: Centre for Independent Social Research.

Dunn, K., 2010. Embodied Transnationalism: Bodies in Transnational Spaces. Population, Space and Place, 16 (1), 1-9.

Estévez, S.M., 2009. Is Nostalgia Becoming Digital? Ecuadorian Diaspora in the Age of Global Capitalism. Social Identities, 15 (3), 393-410.

Garcés-Mascareñas, B., 2010. Legal Production of Illegality in a Comparative Perspective. The Cases of Malaysia and Spain. Asia Europe Journal, 8 (1), 77-89.

Gardner, A., Pessoa, S., Diop, A., Al-Ghanim, K., Trung, K.L. and Harkness, L., 2013. A Portrait of Low-Income Migrants in Contemporary Qatar. Journal of Arabian Studies, 3 (1), 1-17.

Gülçür, L. and İlkkaracan, P., 2002. The "Natasha" Experience: Migrant Sex Workers from the Former Soviet Union and Eastern Europe in Turkey. Women's Studies International Forum, 25 (4), 411-421.

Hamel, J.-Y., 2009. Information and Communication Technologies and Migration. Human Development Research Paper (HDRP) Series, 39.

Hannaford, D., 2015. Technologies of the Spouse: Intimate Surveillance in Senegalese Transnational Marriages. Global Networks, 15 (1), 43-59.

Hiller, H.H. and Franz, T.M., 2004. New Ties, Old Ties and Lost Ties: The Use of the Internet in Diaspora. New Media \& Society, 6 (6), 731-752.

Horst, H.A., 2006. The Blessings and Burdens of Communication: Cell Phones in Jamaican Transnational Social Fields. Global Networks, 6 (2), 143-159.

Human Rights Watch, 2009. 'Are You Happy to Cheat Us?': Exploitation of Migrant Construction Workers in Russia. New York: Human Rights Watch.

Hunter, A., 2015. Empowering or Impeding Return Migration? ICT, Mobile Phones, and Older Migrants' Communications with Home. Global Networks, 15 (4), 485-502.

Ilkhamov, A., 2013. Labour Migration and the Ritual Economy of the Uzbek Extended Family. Zeitschrift für Ethnologie, 138 (2), 259-284.

Ito, M. and Okabe, B., 2005. Technosocial Situations: Emergent Structurings of Mobile e-mail use. In: M. Ito, B. Okabe and M. Matsuda, eds. Personal, Portable, Pedestrian: Mobile Phones in Japanese Life. Cambridge, MA: MIT Press, 257-276. 
Kikuta, H., 2016. Remittances, Rituals and Reconsidering Women's Norms in Mahallas: Emigrant Labour and its Social Effects in Ferghana Valley. Central Asian Survey, 35(1), 91-104.

Laruelle, M., 2007. Central Asian Labor Migrants in Russia: The 'Diasporization' of the Central Asian States? The China and Eurasia Forum Quarterly, 5, 101-119.

Laruelle, M., 2013. Migration and Social Upheaval as the Face of Globalization in Central Asia. Leiden and Boston: BRILL.

Ledeneva, A.V., 2013. Can Russia Modernise?: Sistema, Power Networks and Informal Governance. Cambridge: Cambridge University Press.

Levitt, P., 2001. Transnational Migration: Taking Stock and Future Directions. Global Networks, 1 (3), 195-216.

Levitt, P. and Schiller, N.G., 2004. Conceptualizing Simultaneity: A Transnational Social Field Perspective on Society. International Migration Review, 38 (3), 1002-1039.

Licoppe, C., 2004. 'Connected' Presence: The Emergence of a New Repertoire for Managing Social Relationships in a Changing Communication Technoscape. Environment and Planning. Part D, Society and Space, 22 (1), 135-156.

Lieberson, S., 1980. A Piece of the Pie: Blacks and White Immigrants Since 1880. Berkeley, CA: University of California Press.

Madianou, M., 2012. Migration and the Accentuated Ambivalence of Motherhood: The Role of ICTs in Filipino Transnational Families. Global Networks, 12 (3), 277-295.

Madianou, M., 2016. Ambient co-presence: Transnational Family Practices in Polymedia Environments. Global Networks, 16 (2), 183-201.

Mallapragada, M., 2006. Home, Homeland, Homepage: Belonging and the IndianAmerican Web. New Media \& Society, 8 (2), 207-227.

Mazzucato, V., Dito, B.B., Grassi, M. and Vivet, J., 2017. Transnational Parenting and the Well-being of Angolan Migrant Parents in Europe. Global Networks, 17 (1), 89-110.

McKay, D., 2006. Translocal Circulation: Place and Subjectivity in an Extended Filipino Community. The Asia Pacific Journal of Anthropology, 7 (3), 265-278.

McLaughlin, J., 2010. Classifying the Ideal Migrant Worker: Mexican and Jamaican Transnational Farmworkers in Canada. Focaal, 2010 (57): 79-94.

Nakamura, L., 2013. Cybertypes: Race, Ethnicity, and Identity on the Internet. London: Routledge.

Nedelcu, M., 2012. Migrants' New Transnational Habitus: Rethinking Migration Through a Cosmopolitan Lens in the Digital Age. Journal of Ethnic and Migration Studies, 38 (9), 1339-1356.

Park, R., 1964. Race and Culture: Essays in the Sociology of Contemporary Man. Glencoe, IL: Free Press.

Perkins, R. and Neumayer, E., 2013. The Ties That Bind: The Role of Migrants in the Uneven Geography of International Telephone Traffic. Global Networks, 13 (1), 79-100.

Pertierra, R., Ugarte, E.F., Pinggol, A., Hernandez, J. and Dacanay, N.., 2002. Txt-ing Selves: Cellphones and Philippine Modernity. Manila: De La Salle University Press.

Pipia, K., 2016. Интолерантность и ксенофобия (Intolerance and Хепорhobia). Moscow: Levada Center.

Pletsch, C.E., 1981. The Three Worlds, or the Division of Social Scientific Labor, Circa 1950-1975. Comparative Studies in Society and History, 23 (4), 565-590.

Pochuev, M., 2015. Law Imposing 10-year Entry Ban on Violators of Sojourn Procedures Comes Into Force [online]. TASS. Available from: http://tass.ru/en/russia/770591 [Accessed 22 Sep 2015]. 


\section{Rustamjon Urinboyev}

Portes, A., Guarnizo, L.E. and Landolt, P., 1999. The Study of Transnationalism: Pitfalls and Promise of an Emergent Research Field. Ethnic and Racial Studies, 22 (2), 217-237.

RANEPA, 2019. Monitoring Ekonomicheskoi Situatsii v Rossii: Tendentsii i Vizovi Sotsial'no-Ekonomicheskogo Razvitiia, No 12 (95) [Monitoring of Economic Situation in Russia. Trends and Challenges of Socio-economic Development, No 12 (95)] [online]. Available from: https://www.ranepa.ru/images/News/2019-07/22-07-20 19-monitoring.pdf?fbclid=IwAR3R2UU3QJS847KvzqS9VeAbDK-ZrZSCoqFGqn FZBzYEZAR2RT0YSUxzPVw [Accessed 23 Jul 2019].

Reeves, M., 2012. Black Work, Green Money: Remittances, Ritual, and Domestic Economies in Southern Kyrgyzstan. Slavic Review, 71 (1), 108-134.

Reeves, M., 2013. Clean Fake: Authenticating Documents and Persons in Migrant Moscow. American Ethnologist, 40 (3), 508-524.

Reeves, M., 2015. Living from the Nerves: Deportability, Indeterminacy, and the "Feel of Law" in Migrant Moscow. Social Analysis, 59 (4): 119-36.

Round, J. and Kuznetsova, I., 2016. Necropolitics and the Migrant as a Political Subject of Disgust: The Precarious Everyday of Russia's Labour Migrants. Critical Sociology, 42(7-8), 1017-1034.

Ruget, V. and Usmanalieva, B., 2011. Social and Political Transnationalism Among Central Asian Migrants and Return Migrants. Problems of Post-Communism, 58 (6), $48-60$.

Ryan, L., Klekowski Von Koppenfels, A. and Mulholland, J., 2015. 'The Distance Between us': A Comparative Examination of the Technical, Spatial and Temporal Dimensions of the Transnational Social Relationships of Highly Skilled Migrants. Global Networks, 15 (2), 198-216.

Ryazantsev, S., 2008. Trudovaya Migratsiya v Stranah SNG i Baltii: Tendetsii, Posledstviya, Regulirovanie. Moscow: Formula Prava.

Schiller, N.G., Basch, L. and Blanc-Szanton, C., 1992. Towards a Definition of Transnationalism. Annals of the New York Academy of Sciences, 645 (1), ix-xiv.

Schmidt, M. and Sagynbekova, L., 2008. Migration Past and Present: Changing Patterns in Kyrgyzstan. Central Asian Survey, 27 (2), 111-127.

Schröder, P. and Stephan-Emmrich, M., 2016. The Institutionalization of Mobility: Wellbeing and Social Hierarchies in Central Asian Translocal Livelihoods. Mobilities, 11(3), 420-443.

Turaeva, R., 2019. Imagined Mosque Communities in Russia: Central Asian Migrants in Moscow. Asian Ethnicity, 20(2), 131-147.

UNPD, 2017. International Migration Report 2017. New York: United Nations Department of Economic and Social Affairs (UN DESA), Population Division, No. ST/ ESA/SER.A/404.

Urinboyev, R., 2016. Migration and Transnational Informality in Post-Soviet Societies: Ethnographic Study of 'Po Rukam' Experiences of Uzbek Migrant Workers in Moscow. In: A.-L. Heusala and K. Aitamurto, eds. Migrant Workers in Russia: Global Challenges of the Shadow Economy in Societal Transformation. London: Routledge, 70-93.

Urinboyev, R., 2017. Establishing an "Uzbek Mahalla" Via Smartphones and Social Media: Everyday Transnational Lives of Uzbek Labor Migrants in Russia. In: M. Laruelle, ed. Constructing the Uzbek State: Narratives of Post-Soviet Years. Boulder, CO: Lexington Books, 119-148.

Urinboyev, R., 2018. Migration, Transnationalism, and Social Change in Central Asia: Everyday Transnational Lives of Uzbek Migrants in Russia. In: L. Marlene and 
S. Caress, eds. Eurasia on the Move. Interdisciplinary Approaches to a Dynamic Migration Region. Washington, DC: George Washington University, Central Asia Program, 27-41.

Urinboyev, R., 2020. Migration and Hybrid Political Regimes: Navigating the Legal Landscape in Russia. Oakland, CA: University of California Press.

Urinboyev, R. and Polese, A., 2016. Informality Currencies: A Tale of Misha, His Brigada and Informal Practices Among Uzbek Labour Migrants in Russia. Journal of Contemporary Central and Eastern Europe, 24 (3), 191-206.

Velayutham, S. and Wise, A., 2005. Moral Economies of a Translocal Village: Obligation and Shame Among South Indian Transnational Migrants. Global Networks, 5 (1), 27-47.

Vertovec, S., 1999. Conceiving and Researching Transnationalism. Ethnic and Racial Studies, 22 (2), 447-462.

Vertovec, S., 2004. Cheap Calls: The Social Glue of Migrant Transnationalism. Global Networks, 4 (2), 219-224.

Warf, B., 2013. Geographies of Global Telephony in the Age of the Internet. Geoforum, 45, 219-229.

Weine, S., Golobof, A., Bahromov, M., Kashuba, A., Kalandarov, T., Jonbekov, J. and Loue, S., 2013. Female Migrant Sex Workers in Moscow: Gender and Power Factors and HIV Risk. Women \& Health, 53 (1), 56-73.

Wilding, R., 2006. 'Virtual' intimacies? Families Communicating Across Transnational Contexts. Global Networks, 6 (2), 125-142.

Williams, B.F., 1989. A Class Act: Anthropology and the Race to Nation Across Ethnic Terrain. Annual Review of Anthropology, 18 (1), 401-444.

Wimmer, A. and Glick Schiller, N., 2002. Methodological Nationalism and Beyond: Nation-State Building, Migration and the Social Sciences. Global Networks, 2 (4), 301-334.

Yoon, K., 2016. The Cultural Appropriation of Smartphones in Korean Transnational Families. In: Sun Lim (ed.), Mobile Communication and the Family. Dordrecht: Springer, 93-108. 